\title{
The Influence of Size on Corporate Culture and Organizational Effectiveness in the Nigerian Banking Industry
}

\author{
Edwinah Amah ${ }^{1} \&$ C. A. Nwuche \\ ${ }^{1}$ Department of Management, Faculty of Management Sciences, University of Port Harcourt, Port Harcourt, Nigeria \\ Correspondence: Edwinah Amah PhD, Department of Management, Faculty of Management Sciences, University of \\ Port Harcourt, Port Harcourt, Nigeria. E-mail: edwina4christ@yahoo.com
}

Received: July 8, 2013

doi:10.5430/ijba.v4n5p15
Accepted: July 26, 2013

Online Published: September 6, 2013

\begin{abstract}
The paper examined the effect of size on corporate culture and organizational effectiveness in the Nigerian banking industry. A total of 388 managers were randomly drawn from a population of 13,339 managers of all the 24 banks in Nigeria. The instruments used for data collection were questionnaire and oral interview. A total of 320 copies of the questionnaire were retrieved and analyzed. Spearman's Rank Correlation Statistical tool was used to test the hypotheses. The findings revealed that size is significantly related to corporate culture and organizational effectiveness. Based on the findings we concluded that size have significant effect on corporate culture and organizational effectiveness. The study therefore recommends that Organizations should have a "big company/small company hybrid" that combines a large corporation's resources and reach with a small company's simplicity and flexibility. Size should be managed effectively to empower workers and improve the competitiveness of organizations.
\end{abstract}

Keywords: organizational effectiveness, corporate culture, organizational size, organizational competitiveness

\section{Introduction}

The ability of organizations to cope, survive and make progress determines how effective they are. Skyrocketing health care cost, increasing workforce diversity, and an economic recession, for example, have forced organizations to "right size" (Cummings and Worley, 1993; 4-5). Whereas structure is important in defining individual responsibilities within the workflow process, a congruent size ensures that individuals carry out these responsibilities with minimum resistance.

Organizations experience poor corporate productivity, grapple with low profitability; they struggle to maintain their market share, and suffer difficulties in expanding their market share. They strive for effectiveness and efficiency, the all time basics of all business problems.

Several researches on how to improve organizational effectiveness have taken place in the past two decades. The difference in performance is often related to the strategy adopted by an organization to achieve its objectives. It has also been argued that strategic group membership and associated collective behaviours are the primary sources of durable differences in organizational profitability and effectiveness (Caves and Porter, 1977; Porter, 1979). People today want increasing work-life balance and holistic approach to life. Managers in Nigerian banks do not focus properly on people management issues as they manage through the rules, systems and procedures. Consequently, unrealistic targets are set and effect on staff feelings and moral climate is often ignored. This results in increased resignations, poor customer services, unethical practices that lead to poor assets quality and loan losses, faulty recruitment and placement processes.

Over the past decade, a great deal has been written about size and the role it plays influencing the relationship between corporate culture and successful performance of organizations (Starbuck, 1965, Rushing, 1966, Child, 1977, Deal and Kennedy, 1982, Peters and Waterman, 1982).

Despite this growth of scholarly publications on the influence of size on corporate culture and organizational effectiveness, little empirical evidence exists in developing countries, especially Nigeria. To bridge this gap in literature, this study examines the relationship between size and corporate culture and organizational effectiveness. 
By exploring the effect of size on corporate culture and organizational effectiveness, organizations can enhance their competitive advantage and effectiveness.

\section{Literature Review}

Size is the organization's magnitude as reflected in the number of people in the organization. Organization size has often been described as an important variable that influences structural design. Organizations have growth as one of their goals. Daft (2003) offered three reasons for the desire for growth. These include organization goals, executive advancement and economic health. Organizations merge to gain stronger market presence. There are many challenges and opportunities for advancement when the number of employees is expanding (Starbuck, 1965; Child, 1977). Greater size gives marketing-intensive companies like banks, power in the market place and increased revenues (Treece, 1993).

Huge resources and economics of scale are needed for many organizations to compete globally. This is responsible for the mergers and acquisitions going on in the Nigerian banking sector. However, small and large organizations have their peculiar characteristics and effects on the culture and effectiveness of the organizations (Daft, 2003). Large organizations are standardized, often mechanistically run, and complex. The complexity offers hundreds of functional specialties within the organization to perform complex tasks and produce complex products (Geeraerts, 1984). Once established, large organizations can be a presence that stabilizes a market for years. It provides longevity, raises and promotions.

Large organizations are associated with vertical and horizontal complexity, more decentralized (Geeraerts, 1984; Hage and Aiken, 1967). Founders and senior managers do not have sufficient time and expertise to process all the decisions that significantly influence the business as it grows. Therefore, decision-making authority is pushed down to lower levels, where incumbents are able to cope with the narrower range of issues under their control (Robey, 1991). They carry out more written communications and documentation. They have bureaucratic culture, which has an internal focus and a consistency orientation for stable environment. The culture supports a methodical approach to doing business (Daft, 2003). Symbols, heroes and ceremonies support cooperation, tradition and following established policies and practices as a way to achieve goals. There is high level of consistency, and collaboration among members. The organization succeeds by being highly integrated and efficient (Daft, 2003).

Small organizations are responsive and flexible and this guarantees them success in a global economy (Deutschmann, 1991; Daft, 2003). Research shows that as global trade has accelerated, smaller organizations have become the norm (Carroll, 1994). Huge investments are giving way to flexible manufacturing and niche marketing as ways to succeed. There is a decrease in average organization size, as most service companies remain small to be more responsive to customers (Carroll, 1994). Small organizations have flat structure and an organic, free-flowing managing style that encourages entrepreneurship and innovation (Daft, 2003; Deutschmann, 1991). Small size of firm encourages motivation and commitment, which are needed for effectiveness. In small organization's top managers can use their personal observation to control (Carter and Keon, 1989; Hsu et al, 1983; Geeraerts, 1984; and Rushing, 1966). This implies that small size eases the problem of control.

The complexities of structural and cultural issues increase exponentially when firms expand their business activities to the international level (Cheah and Garvin, 2004). In this case, phases of cultural development have to be planned, and organizational structure has to be redesigned to absorb changes in control and coordination mechanisms (Barlett and Ghoshal, 1998) this is especially true given the nature of service operations that largely demand responsiveness to the local environment. Recent research on organizations shows that in rapidly growing organizations, administrators grow faster than line employees. In declining organizations they decline more slowly. This implies that administrative and staff personnel are often the first hired and the last fired (Marsh and Mannari, 1989). In large organizations, top administrators are a small percent of total employment. They, however, spend more on overhead because of the number of staff involved.

Jack Welch, Chairman of General Electric, called for a big company/small company hybrid" that combines a large corporation's resources and reach with a small company's simplicity and flexibility. Some big companies like Johnson, Hewlett-Packard, AT\&T and Even General Motors are already effecting this suggestion. These companies have all undergone massive reorganizations into groups of small companies to capture the mind-set and advantages of smallness. Daft (2003) further argued that:

"A full-service, global firm needs a strong resource base and sufficient complexity and hierarchy to serve clients around the world. Large or growing companies can retain the flexibility and customer focus of smallness by decentralizing authority and cutting layers of the hierarchy" (pg. 165). 
Banks in Nigeria have expanded and established several branches to enable them bring their services closer to the customers. They have also appropriated the advantage of the simplicity and flexibility associated with small companies in their branches.

A culture that encourages the training of employees together yearly at Family Dollar is attributed with the keeping of employees connected to one another and increased productivity (Stoner et al, 2001). Culture is reinforced constantly through the creation of stories, heroes, rites, slogans and ceremonies (Robbins, 2003; Daft, 2003; Stoner et al, 2001). The founder of Body shop Anita Roddick is reported to have used a strong corporate culture built on social activism to establish a successful organization (Stoner et al, 2001). Although some large organizations embrace some of the new rules, in general it is easier for small, new businesses to develop this type of culture from the start than for large, established organizations to change an existing culture (Stoner et al, 2001). The research conducted within the scope of the Carl Bertelsmann Prize 2003 has proven that a corporate culture, if designed humanely and efficiently and exemplary leadership beha behavior rank among the decisive success factors for many European companies. Lejeune and Vas, (2009) also reported that the cultural change induced by accreditation seems to be correlated with a positive impact on performance.

Effectiveness is a broad concept and is difficult to measure in organizations (Daft, 2003). It takes into consideration a range of variables at both the organizational and departmental levels. It evaluates the extent to which the multiple goals of the organization are attained. Organizations are large, diverse and fragmented and tend to perform many activities simultaneously with various outcomes (Weick and Daft, 1982). It is difficult for managers to evaluate performance on goals that are not precise or measurable (Blenkhorn and Gaber, 1995). However, performance measurement that is tied to strategy execution can help organizations reach their goals (Rose, 1991).

Daft (2003) has identified two major approaches to measurement of organizational effectiveness - the traditional and contemporary approaches. The traditional approaches include the goal approach, the system resource approach and the internal process approach. The goal approach to organizational effectiveness which this study considers is concerned with the outputs, whether the organization achieves its goals in terms of its desired level of outputs (Strasser et al., 1981). It is based on the fact that organizations have goals they are expected to achieve.

Hall and Clark, (1980) argue that the important goals to consider are the operative goals and not the official goals. The official goals tend to be abstract and difficult to measure while the operative goals reflect the activities the organization is actually performing. The goal approach is used in business organizations because output goals can be readily measured (Daft, 2003). Top managers can report on actual goals of the organization since such goals reflect their values (Pennings and Goodman, 1979). Once goals are identified, subjective perceptions of goal achievement can be obtained if quantitative indicators are not available.

Effectiveness is measured by profitability, productivity, and market share in this study. Profit has been defined as the money a business earns above and beyond what it spends for salaries expenses, and other costs (Nickels et al., 2011). Profit is one of the major reasons for venturing into business. Profitability therefore, means a state of producing a profit or the degree to which a business is profitable. Profitability is the primary goal of all for-profit business ventures (Amah, 2006). Without profitability the business will not survive in the long run. Conversely a business that is highly profitable has the ability to reward its owners with a large return on their investment. According to Thompson and Strickland (2001:9, 42):

Achieving acceptable financial result is crucial... Achieving acceptable financial performance is a must, otherwise the organization's financial standing can alarm creditors and shareholders, impair its ability to fund needed initiatives and perhaps even put its very survival at risk.

This makes measuring current and past profitability and projecting future profitability a very important issue. Profitability has been identified as criteria for organizational effectiveness by many authors (Friedlander and Pickle, 1968; Child, 1974 and 1975; Negandhi and Reimann, 1973; and Maheshwari, 1980). It takes a productive firm to be profitable; this brings us to our next measure of organizational effectiveness, which is productivity.

Productivity is basic to organizational effectiveness. Productivity is defined by Amah (2006) as "the measure of how efficiently and effectively resources (inputs) are brought together and utilized for the production of goods and services (out puts) of the quality needed by society in the long term". This implies that productivity is combination of performance and economic use of resources. High productivity indicates that resources are efficiently and effectively utilized and waste is minimized in the organization. Productivity balances the efforts between different economic, social, technical and environmental objectives (Amah, 2006). High productivity provides more profit for investors and promotes the development of the enterprise. Productivity measurement indicates areas for possible 
improvements and shows how well improvement efforts are fairing. It helps in the analysis of efficiency and effectiveness. It can stimulate improvement and motivate employees (Prokopenko, 1987).

Productivity is related to the amount of output produced relative to the amount of resources (time and money) that go into the production. Productivity is expressed in terms of cost for a unit of production; "units produced per employee" or "resource cost per employee" (Daft, 2003). Productivity improves, when the quantity of output increase relative to the quantity of input. It includes measures such as time minimization, cost minimization and waste minimization. Speed and time are important resources, organizations seek to maximize speed and minimize time. The way they do these indicates how efficient and productive they are. However, to be effective organizations need to maintain and improve their market share.

Market Share refers to the company's sales as a percentage of the sales in its target market (Czinkota et al., 1997). This means that in strategic management and marketing, market share is the percentage or proportion of the total available market or market segment that is being serviced by a company. It can be expressed as a company's sales revenue (from that market) divided by the total sales revenue available in that market. It can also be expressed as a company's unit sales volume (in a market) divided by the volume of units sold in that market. Market share (or brand share) is the share of overall market sales for each brand. Market share can be quoted in terms of volume (e.g. the brand has a 10\% share of the total number of units sold) or in terms of value (Czinkota et al., 1997). According to Czinkota et al., (1997), the measure of share and concept of prospects are important because they describe the extra business that a producer can reasonably look for, and when to obtain it. Increasing market share is one of the most important objectives used in business. The main advantage of using market share is that it abstracts from industry-wide macro environmental variables such as the state of the economy or changes in tax policy. According to the national environment, the respective share of different companies changes and hence this causes change in the share market value; the reason can be political ups and downs, and disaster, any happenings or mis-happening.

Market share has the potential to increase profits. Small market share increases, mean very large sales increases. Studies have shown that, on average, profitability rises with increasing market share (Kotler and Armstrong, 2001). Because of these findings, many companies have sought to expand market shares to improve profitability. Kotler and Armstrong (2001) argue that higher market share tend to produce higher profits only when unit costs fall with increased market share, or when the company offers a superior quality product and charges a premium price that more than covers the cost of offering higher quality. Market share is important because it enables one to know the strength of the organization whether they are leaders or minor players and also if the organization is still holding, gaining or losing share of its target market (Kotler, 1999). According to Kotler and Armstrong (2001), organizations need to protect their current business against market attacks while trying to expand by first, fixing weaknesses that can provide opportunities for their competitors, second, keeping costs down and its prices in line with the value the customers see in the brand, third, by continuous innovation and finally by increasing its competitive effectiveness and value to customers. From the foregoing the following hypothesis was derived.

$\mathrm{Ho}_{1}$ : There is no significant relationship between size and the influence of culture on organizational effectiveness.

\section{Research Methodology}

This correlational study was conducted as a cross-sectional survey. The study units for data generation were managers in the banks and the micro-level of analysis was adopted. The population of the study was 13, 339 managers of all the 24 banks in Nigeria and the sample size of 388 managers was determined using the Yaro Yamen's formula (Baridam, 2001). After cleaning, 320 copies of the instrument were used for the analysis. In selecting the respondents the simple random sampling technique was adopted. Size - A five -item size scale was developed for this study. The dependent variable, corporate culture and organizational effectiveness was measured by adaptability, mission, involvement, consistency, profitability, productivity, and market share. Adaptability -Thirteen- item adaptability scale was developed. Mission- A nine-item mission scale was developed for this study. Involvement $-\mathrm{A}$ seven- item involvement scale was developed for this study. Consistency - A thirteen - item consistency scale was developed. A five-item profitability scale was developed for this study. A two-item productivity scale and a seven-item market share scales were also developed for the study. The measures all used a 5-point Likert scale- (ranging from 1-strongly disagree to 5-strongly agree. For test of reliability of the scale, the following Cronbach's alpha coefficients were obtained: Size (0.79), Adaptability (0.73), Mission (0.70), Involvement (0.73), Consistency (0.79), Profitability (0.72), Productivity (0.76), and Market share (0.73). In accordance with Nunnaly (1978) model, which recommends a bench mark of 0.70 , the reliability levels of the study scale are acceptable. Spearman's Rank Correlation Statistical tool was used to test the hypothesis. The result as presented was obtained. 


\section{Research Results and Findings}

Frequencies and descriptives were used in our primary analysis which focused on the study demographics and univariate analysis respectively. The results show that $57.1 \%$ of the respondents were males while $42.9 \%$ were females. $23.8 \%$ of the respondents have spent $0-9$ years on their jobs while $30.6 \%$ have spent between 10 and 20 years. $46.6 \%$ of the respondents have spent over 20 years on their present employments. On educational qualification, we had the following distribution: $60.3 \% \mathrm{HND} / \mathrm{BSc}, 39.7 \%$ Masters. $23.1 \%$ were single while $76.9 \%$ were married.

The result of the univariate analysis is shown in Table 1. The mean scores (x) obtained for Size in Nigerian banks is weighty $(x=3.9)$. This means that the banks have good size to enable them have a good culture that has impacted on their performance. The mean scores for corporate culture variables (adaptability, 4.29, mission, 3.9, involvement, 4.3 and consistency, 4.1) is also high.

Table 1. Descriptive statistics of study variables

\begin{tabular}{lllllc}
\hline & N & MEAN & STANDARD DEVIATION & SKEWNESS & \\
\hline & Statistics & Statistics & Statistics & Statistics & Standard error \\
\hline Size & 320 & 3.9309 & .47266 & -.319 & .136 \\
Adaptability & 320 & 4.2974 & .25037 & -.475 & .136 \\
Mission & 320 & 3.9916 & .60377 & 2.795 & .136 \\
Involvement & 320 & 4.3491 & .30931 & -.150 & .136 \\
Consistency & 320 & 4.1207 & .42054 & -.558 & .136 \\
Profitability & 320 & 4.4012 & .45070 & -.352 & .136 \\
Productivity & 320 & 4.2438 & .44039 & .291 & .136 \\
Market share & 320 & 3.9232 & .49134 & -212 & .136 \\
\hline
\end{tabular}

Source: SPSS Output on the analysis of Research Data.

The mean score of profitability $(x=4.40)$ also shows that the size and corporate culture in the banks is associated with the high level of profitability. In other words, the size and the existing culture have led to a high level of profitability in the banks in Nigeria. The mean score of productivity $(\mathrm{x}=4.24)$ also shows that the size and culture in the banks have positively impacted on the banks level of productivity. Similarly, the mean score of banks market share is high $(\mathrm{x}=3.9)$ as a result of the size and the corporate culture. Satisfied customers help to advertise their respective banks leading to increase in market share.

Table 2

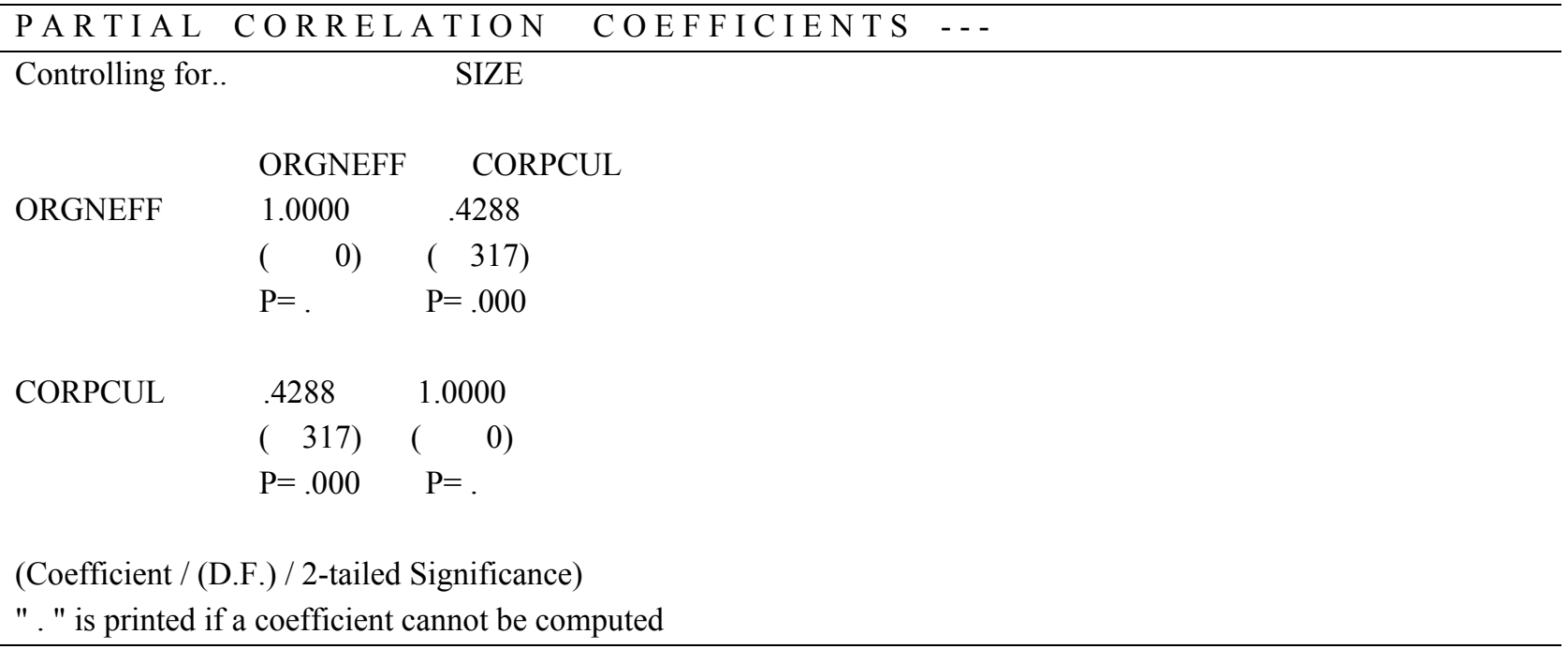

Source: SPSS Output on the analysis of Research Data.

\section{Relationship between Size of Organization and the Influence of Corporate Culture on Organizational Effectiveness}

This hypothesis states "size of organization does not significantly affect the influence of corporate culture on organizational effectiveness. The hypothesis sought to examine the relationship between size of organization and the 
influence of corporate culture on organizational effectiveness. The statistical tool used to test this hypothesis involving these three variables is the Partial correlation coefficient in the SPSS package. Organizational effectiveness and corporate culture controlled for size of organization gives a coefficient of $(0.426 \mathrm{P} \leq 0.01)$ (see Table 2$)$. This shows that there is a positive significant relationship between size and the influence of corporate culture on organizational effectiveness. This implies that increase in the size of organization is associated with increase in the influence of corporate culture on organizational effectiveness.

The literature review of the present study suggested a positive relationship between size and the influence of corporate culture on organizational effectiveness (Daft 2003). Our finding supports an earlier report by Treece (1993) that greater size gives marketing intensive companies like banks, power in the market place and increased revenues. Several reasons account for this positive and significant relationship.

Large organizations have bureaucratic culture, which has an internal focus and a consistency orientation for stable environment. The culture supports a methodological approach to doing business. Large organizations tend to have high level of consistency, conformity and collaboration among members.

One respondent in one of the banks said their organization is effective because it combines a large corporation's resources and reach with a small company's simplicity and flexibility.

We therefore reject the hypothesis that says that the "size of organization does not positively and significantly affect the influence of corporate culture on organizational effectiveness". For the research question that says "How does organizational size affect the influence of corporate culture on organizational effectiveness?" Our finding indicates that the size of organization positively affects the influence of corporate culture on organizational effectiveness.

\section{Discussion}

This hypothesis states that the size of organization does not affect the influence of corporate culture on organizational effectiveness. We found that the size of organization affects the influence of corporate culture on organizational effectiveness.

Size refers to the organizations' magnitude as reflected in the number of people in the organization. Daft (2003) offered three reasons why organization's desire increase in size or have growth as one of their goals. These include organization goals, executive advancement and economic health. Treece (1993) argued that greater size gives marketing intensive companies like banks, power in the market place and increased revenues. This suggests why the size of an organization could affect corporate culture's influence on organizational effectiveness. The culture of large organization differs from that of small organizations and it influences effectiveness.

Daft (2003) stated that small and large organizations have their peculiar characteristics and effects on the culture and effectiveness of the organization. Large organization are standardized, often mechanistically run, and complex. Geeraerts (1984) argued that the complexity of large organizations' offers hundreds of functional specialties with it to perform complex tasks and produce complex products. This implies that once established, large organizations can be a presence that stabilizes a market for years. It provides longevity, raises and promotion.

Large organizations are associated with vertical and horizontal complexity, more decentralized (Geeraerts, 1984; Hage and Aiken, 1967). Large organizations tend to have bureaucratic culture, which has an internal focus and a consistency orientation for stable environment. Daft (2003) argued that the culture of large organization supports a methodical approach to doing business. This implies that there is high level of consistency, conformity, and collaboration among members. The organization succeeds by being highly integrated and efficient (Daft, 2003). This explains why the size of organization affects the influence of corporate culture on organizational effectiveness. In Nigeria the recapitalization with its subsequent mergers and acquisition has made many banks increase in size. Such banks now enjoy the benefits accruing to large organizations.

Deutschmann (1991) and Daft (2003) stated that small organizations are responsive and flexible and this guarantees them success in a global economy. Carrol (1994) reported that as global trade has accelerated, smaller organizations have become the norm. He argued that there is a decrease in average organization size, as most service companies remain small to be responsive to customers. This implies that small size of firm encourages motivation and commitment, which are needed for effectiveness. Small size eases the problem of control (Carter and Keon, 1989). These explain further why size affects the influence of corporate culture on organizational effectiveness.

Some Nigerian banks have expanded their business activities to the international level, for such banks the complexities of structural and cultural issues increase exponentially according to Cheah and Garvin (2004). In this case, phases of cultural development have to be planned and organization structure has to be redesigned to absorb 
changes in control and coordination mechanisms (Barlett and Ghoshal, 1995). This is especially true given the nature of service operations that largely demand responsiveness to the local environment.

Considering the advantages of small and large organizations, Jack Welch, Chairman of General Electric, called for a "big company/small company hybrid" that combines a large organization's resources and reach with a small company's simplicity and flexibility. This suggestion, which is already being effected by some big companies like Johnson and Johnson, Hewlett-Packard, AT\&T and even General Motors, can be effected in the Nigerian banking industry to capture the mindset and advantages of smallness.

Like Daft (2003) argued, a full-service global bank needs a strong resource base and sufficient complexity and hierarchy to serve clients around the world. Large or growing banks can retain the flexibility and customer focus of smallness by decentralizing authority and cutting layers of the hierarchy. The size of organization positively affects the influence of corporate culture on organizational effectiveness.

For the research question that says "How does organizational size affect the influence of corporate culture on organizational effectiveness?" Our finding indicates that the size of organization positively affects the influence of corporate culture on organizational effectiveness. Large banks with strong resource base and many branches that are responsive and flexible tend to be more effective because they are combining the advantages of large and small organizations. Thus size of organization positively affects the influence of corporate culture on organizational effectiveness. The positive influence of corporate culture on organizational effectiveness increases with large, responsive and flexible organization.

\section{Conclusion}

The findings of this research imply that one of the most important contributions a manager or executive can make is the culture they create. People act because of internalised values, not because of external control. This frees the managers from some of the demands of constant oversight and administrative control of their organizations. This freedom enables the manager to concentrate on the most important leadership task of all: "planning what happens next".

Managing culture requires a significant portfolio of skills in the four concepts the model - adaptability, mission, involvement and consistency.

The size of organization affects the influence of corporate culture on organizational effectiveness. The positive influence of corporate culture on organizational effectiveness increases with increase responsiveness and flexibility associated with small size. Big banks achieve this through the opening of several branches and the decentralization of activities.

\section{Recommendations}

Managers should build a culture as an explicit role with a set of objectives, as it is a consensual system of regulation that reaches far beyond any system of bureaucratic or administrative control.

Organizations should have a "big company/small company hybrid" that combines a large corporation's resources and reach with a small company's simplicity and flexibility.

Size of organization should be managed effectively to empower workers and improve the competitiveness of organizations.

A culture that is adaptive, yet highly consistent, and responsive to individual involvement, but within the context of a strong shared mission, will be most effective.

\section{Limitations of the Study}

The fact that this is a study of the banking industry, limits the extent to which generalizations of any outcome of this study can be applied to all other sectors and industries in the Nigerian economy. The scarcity of relevant literature on the subject matter was manifest in that most of the articles and books consulted by the researcher were foreign oriented. Having been written by authors mainly in Europe and America, these articles and books portrayed the situation in these countries. However, few literatures written by Nigerians and indigenes of other less developed countries were also consulted which proved helpful.

Not all the questionnaires given out were retrieved. Some respondents were reluctant to give information about their organization because of fear that such information will get to their competitors. Sometimes, the respondents provide only information they are willing or able to provide which may not give the validity of the situation. However, this 
was taken care of as other means of data collection were also used. Besides, not all respondents were economical with their response. The environment is held constant.

\section{References}

Amah, E. (2009). Corporate Culture and Organizational Effectiveness. A Study of the Nigerian Banking Industry. An Unpublished PhD Thesis of the Faculty of Management Sciences, University of Port Harcourt, Nigeria.

Amah, E., \& Weje, M. (2004). Fundamentals of Management. Davidstone Publishers, Port Harcourt.

Baridam, D.M. (2001). Research Methods in Administrative Sciences ( $3^{\text {rd }}$ ed.). Sherbrooke Associates Port Harcourt.

Barney, J. B. (1986). Organizational Culture: Can it be a Source of Sustained Competitive Advantage? Academy of Management Review, 11, 656-665.

Bartlett, C.A., \& Ghoshal, S. (1995). Rebuilding Behavioural Context: Turn, Process RE-Engineering into People Re-juvination. Sloan Management Personnel, Fall, 11-23.

Bateman, T.S., \& Snell, S.A. (1999). Management: Building Competitive Advantage (4 ${ }^{\text {th }}$ ed.). McGraw Hills Inc.

Blenkhorn, D.L., \& Gaber, B. (1995). The Use of 'Warm Fuzzies' to Access Organizational Effectiveness. Journal of General Management, 21(2), (winter), 40-51.

Burt, R. S., Gabbay, S. M., Holt, G., \& Mora, P. (1994). Contingent Organization as Net Work Theory. The Culture Performance Contingent Function. Act a Sociological, 37(4), 345-370. http://dx.doi.org/10.1177/000169939403700404

Carroll, G.R. (1994). Organizations...the smaller they get. California Management Review, 37(1), (fall), 28-41.

Carter, N. M., \& Keon, T.L. (1989). Specialization as Multidimensional Construct. Journal of Management Studies, 26, 11-28. http://dx.doi.org/10.1111/j.1467-6486.1989.tb00714.x

Caves, R. E., \& Porter, M. E. (1977). From Entry Business: Conjectural Decisions and Contrived Deterrence to New Competition. Quarterly Journal of Economics. http://dx.doi.org/10.2307/1885416

Chatman, J. A. (1998, Dec.). Being different yet feeling similar: the influence of Demographic Composition and organizational culture on work processes and outcomes. Administrative Science Quarterly. http://dx.doi.org/10.2307/2393615

Cheah, C.Y.J., \& Garviin, M.J. (2004). An Open Framework for Corporate Strategy in Construction. Engineering, Construction and Architectural Management, II(3), 176-188. http://dx.doi.org/10.1108/09699980410535787

Child, J. (1977). Organizations. New York: Harper and Row, Chp 7.

Christensen, E. W. (1999). An Exploration of Industry, Culture and Revenue Growth. Organization Studies, Summer. http://dx.doi.org/10.1177/0170840699203002

Cummings T.G., \& Worley C.O. (1993). Organization Development and Change (5 ${ }^{\text {th }}$ ed.). New York; West Publishing Company.

Daft, R.L. (2003). Organization Theory and Design. Southwestern College Publishing, Cincinnati, Ohio.

Deal T.E., \& Kennedy A.A. (1982). Corporate Cultures. Reading, MA: Addison-Wesley.

Denison, D.R. (1984). Bringing Corporate Culture to the Bottom line. Organizational Behaviour, 13(2), 5-22.

Denison, D.R. (1985). Corporate Culture and Organizational Effectiveness: A Behavioural Approach to Financial Performance. Wiley-Interscience.

Denison, D.R. (1990). Corporate Culture and Organizational Effectiveness. New York: Wiley.

Denison, D.R., \& Mishra A.K. (1995). Toward a theory of Organizational Culture and effectiveness. Organization Science, 6, 204-223. http://dx.doi.org/10.1287/orsc.6.2.204

Deutschman, A. (1991, October). America's Fastest Risers. Fortune 7, 46-57.

Fubara, I. (2011). Introduction to Business Planning and Forecast. Aba: Boston.

Geeraerts G. (1984). The Effect of Ownership on the Organizational Structure in Small Firms. Administrative Science Quarterly, 29, 232-37. http://dx.doi.org/10.2307/2393175

Gordon, G.G., \& Ditomaso, N. (1992, Nov). Predicting Corporate Performance From Organizational Culture. Journal of Management Studies, 793-98. 
Hage, J., \& Aiken, M. (1967). Relationship of Centralization to Other Structural Properties. Administrative Science Quarterly, 12, 72-91. http://dx.doi.org/10.2307/2391213

Hansen, G.S., \& Wernerfelt, B. (1989). Determinants of Firm's Performance: The Relative Importance of Economic and Organizational Factors. Strategic Management Journal, 10, 399-411. http://dx.doi.org/10.1002/smj.4250100502

Hsu, K., March, R.M., \& Mannari, H. (1983). An Examination of the Determinants of Organizational Structure. American Journal of Sociology, 88, 975-96. http://dx.doi.org/10.1086/227766

Kotter, J.P., \& Heskett, J.L. (2011). Corporate Culture and Performance. New York: The Free Press.

Marsh, R.M., \& Mannari, H. (1989). The Size Imperative? Longitudinal Tests. Organizational Studies, 10, 83-95. http://dx.doi.org/10.1177/017084068901000105

Nickels, G., McHugh, J.M., \& McHugh, S.M. (2011). Understanding Business ( ${ }^{\text {th }}$ ed.). Irwin McGraw-Hill New York.

Peters, T.J., \& Waterman, R.H. (1982). In Search of Excellence: lessons from America's Best Run Companies. New York: Harper and Row.

Porter, M. E. (1979). The Structure Within Industries and Companies Performance. Review of Economic Statistics. http://dx.doi.org/10.2307/1924589

Robey, D. (1991). Designing Organizations ( $3^{\text {rd }}$ ed.). Homewood IL:Irwin.

Rose, F. (1991, April). New Quality Means Service Too. Fortune, 22, 99-108.

Rushing, W.A. (1966). Organizational Rules and Surveillance: A Proposition in Comparative Organizational Analysis. Administrative Science Quarterly, 10, 423-43. http://dx.doi.org/10.2307/2391569

Schein, E. H. (1985). Organizational Culture and Leadership: A Dynamic View San Francisco. Jossey-Bass.

Sorensen, J.B. (2002, March). The Strength of Corporate Culture and the Reliability of Firm Performance. Administrative Science Quarterly, 70-91. http://dx.doi.org/10.2307/3094891

Starbuck, W.H. (1965). Organizational Growth and Development. In James March (Ed.), Handbook of organizations. New York: Rand McNally.

Stewart, T. A. (1997, March). CEO Pay: Mom Would Be Proud. Fortune, 135(6), 119-20.

Stoner, J.F., Freeman, R.E., \& Gilber, D.R. (2001). Management. NJ Englewood Cliff: Prentice - Hall Inc.

Treece, J.B. (1993). Sometimes, You've Still Gotta Have Size. Business Week Enterprise, 2000-2001.

Weick, K.E., \& Daft, R. L. (1982). The Effectiveness of Interpretation Systems. In Kim S. Cameron and David A. Whetten (Eds.), Organizational Effectiveness: A Comparison of Multiple Models. New York: Academic Press.

Weje, M. (2011). Effective Job Creation: The Way Forward for Sustainable Economic Development in Nigeria. Lecture Seminar Module. 